\title{
DECONTAMINATION TREATMENT FOR CONTROLLING BACTERIAL PATHOGENS ON CHICKEN CARCASSES SKIN
}

\author{
AMANY F. ALEXAN
}

Animal Health Research Institute, ARC, Ministry of Agriculture, Dokki, Giza, Egypt

(Manuscript received 30 October 2006)

\section{Abstract}

A comparative study on the effect of different decontamination treatments to reduce inoculated bacterial pathogens and spoilage micro flora in chicken wings skin was conducted. Uninoculated and inoculated raw chicken wings with $L$. monocytogenes, $S$. Typhimurium and $S$. aureus were dipped in tap water (control), 8 $\%$ ( $\mathrm{pH} 12.59), 10 \%(\mathrm{pH} \mathrm{12.68)}, 12 \%(\mathrm{pH} 12.75) \mathrm{w} / \mathrm{v}$. Trisodium phosphate (TSP) solution, $1 \%(\mathrm{pH} 1.8) \mathrm{v} / \mathrm{v}$ lactic acid, $2 \%(\mathrm{pH}$ $1.8-2) \mathrm{v} / \mathrm{v}$ acetic acid and combination of the decontamination treatment and hot water $70^{\circ} \mathrm{C}$ were assessed. Surface $\mathrm{pH}$ value and bacterial count of chicken wings were determined immediately after treatment (day 0 ) and after 1, 3 and 5 days of refrigerated storage at $4^{\circ} \mathrm{C}$. Compared with water dipping, all the decontamination treatments significantly $(P<0.05)$ reduced inoculated bacterial pathogens. The concentration of TSP was a significant factor in reducing bacterial populations. The TSP and lactic (or acetic) acid treatment resulted in relatively high $(8.3 \pm 0.15-9.07 \pm 0.04)$ and low $(6.4 \pm 0.07-6.32 \pm 0.07)$ surface $\mathrm{pH}$, respectively, initially and throughout storage. The decontamination treatment retarded the growth of spoilage micro flora on uninoculated chicken wings, and thus, potentially extending the shelf life. The interaction between decontamination treatment and hot water $70^{\circ} \mathrm{C}$ was more effective in reducing count for spoilage micro flora than for inoculated bacteria. It is concluded that decontamination treatment (especially $12 \%$ TSP and $1 \%$ lactic acid) combined with hot water $70^{\circ} \mathrm{C}$, markedly improved the bacterial safety and increased the refrigerated shelf life of chicken carcasses.

\section{INTRODUCTION}

Chickens naturally carry a wide variety of bacteria into the processing plant, and this micro flora can be transferred onto the surface of carcasses during processing. Although most of these bacterial species are non-pathogenic, they may adversely affect the shelf life of raw poultry (Capita et al., 2002).

Food borne illness cases caused by the consumption of contaminated poultry meat are due to improper cooking or handling (Ryser, 1999). In addition, raw poultry products are refrigerated or frozen prior to cooking; the growth of psychrotrophic pathogens in refrigerated poultry product is of food safety concern.

Experiments with Gram positive and Gram negative flagellated and nonflagellated bacterial species showed that all attach to chicken skin; there was generally 
a linear increase in rate of attachment from 0.25 to $60 \mathrm{~min}$. during exposure to microorganisms (Lillard, 1985).

Since microbial contamination is primarily on the surface of carcasses, several studies were directed to eliminate or substantially decrease bacterial population on poultry carcasses. A number of antimicrobial treatments for chicken carcasses had been studied. Recently, Del Rio et al. (2006) found that Pseudomonas fluorescence (a spoilage organism) was more susceptible to TSP treatment than L. monocytogenes when inoculated at $10^{(6)} \mathrm{cfu}^{\text {per }}\left(\mathrm{g}^{-1)}\right.$ on chicken legs.

So, the present study was undertaken with two aims, first, to explore the efficacy of certain chemicals dipping and/or hot water in reducing spoilage and microbial populations of refrigeration storage $4^{\circ} \mathrm{C}$ poultry wings inoculated with $L$. monocytogenes, S. Typhimurium and $S$. aureus, Second, to assess the mechanism by which decontamination treatment kills surface bacteria on poultry.

\section{MATERIALS AND METHODS}

\section{Preparation of bacterial inoculums}

L. monocytogenes, S. Typhimurium and S. aureus were obtained from Animal Health Research Institute, Serology Unit. All had been originally isolated from chicken carcasses. Each strain was loop-transferred from a24 h culture to $10 \mathrm{ml}$ triptych soya broth $\mathrm{pH} 7.3$ (Difco) and incubated at $30^{\circ} \mathrm{C}$ for $24 \mathrm{~h}$ to achieve populations of approximately $10^{9} \mathrm{CFU} / \mathrm{ml}$. Inocula of L. monocytogenes, $S$. Typhimurium and $S$. aureus were prepared separately by diluting $10 \mathrm{ml}$ of the suspension with $90 \mathrm{ml}$ of sterile $0.1 \% \mathrm{w} / \mathrm{v}$ peptone water (Oxoid) to yield $10^{8} \mathrm{CFU} / \mathrm{ml}$.

\section{Sample inoculation}

Chicken wings were collected from same poultry processing plant immediately after evisceration, and transported in an ice bag to the laboratory. Four main groups of chicken wings were used. Three equal main groups were immersed for $5 \mathrm{~min}$ in suspension of $10^{8} \mathrm{CFU} / \mathrm{ml}$ of L. monocytogenes, S. Typhimurium and S. aureuS, respectively. After inoculation, chicken wings were kept for $30 \mathrm{~min}$ at room temperature to allow the bacteria to attach the skin. Populations of each bacterial species on chicken wings were determined. The remaining main groups were kept as uninoculated wings, and population of spoilage bacteria was determined (Rodriguez de Ledesma et al., 1996).

\section{Decontamination treatment}

According to Rodriguez de Ledesma et al. (1996), each main group of chicken wings was randomly divided into 12 subgroups. For each main group, samples in one subgroup were dipped into sterile tap water (control) for $15 \mathrm{~min}$. Samples in three 
subgroups were dipped into $8 \%(\mathrm{pH} 12.59), 10 \%(\mathrm{pH} 12.68)$ or $12 \%(\mathrm{pH} 12.75)$ $\mathrm{w} / \mathrm{v}$ Trisodium phosphate (TSP) (Merck) solution for $15 \mathrm{sec}$, respectively. Samples in other two subgroups were dipped into $1 \%(\mathrm{pH} 1.8) \mathrm{v} / \mathrm{v}$ lactic acid (EA Chemicals) and $2 \%(\mathrm{pH} 1.8-2) \mathrm{v} / \mathrm{v}$ acetic acid (Adwic) for $15 \mathrm{sec}$, respectively. The concentration of acetic acid was selected because the $\mathrm{pH}$ value was similar to that of the lactic acid solution used. Samples in the five subgroups were dipped in TSP ( $8 \%$, $10 \%$ and $12 \%$ ), lactic acid (1\%) and acetic acid ( $2 \%)$, respectively, as described above, followed by dipping in hot water $70^{\circ} \mathrm{C}$ for $5 \mathrm{sec}$. Samples in the remaining last subgroup were dipped in hot water $70^{\circ} \mathrm{C}$ for $15 \mathrm{sec}$. After treatment, chicken wings were drained for $15 \mathrm{~min}$. at room temperature. The samples were placed in sterile bags and stored at $4^{\circ} \mathrm{C}$. All samples were evaluated for bacteriological examination, and the first six subgroups for $\mathrm{pH}$ values after $0,1,3$ and 5 days of storage. On day 0 , samples were tested immediately after the inoculation and dipping treatment had been completed.

\section{Bacteriological examination and $\mathrm{pH}$ determination}

For each decontamination treatment, half of the chicken wings was used for bacteriological examination, and the other half for $\mathrm{pH}$ determination. For bacterial count, each sample was prepared by excising $5 \mathrm{~g}$ of skin with a sterile knife blade. The samples were placed in a sterile blender containing $45 \mathrm{ml}$ of sterile $0.1 \% \mathrm{w} / \mathrm{v}$ buffered peptone water and macerated in a blender for $2 \mathrm{~min}$. Serial dilutions in sterile $0.1 \% \mathrm{w} / \mathrm{v}$ peptone water were prepared from this homogenate, $0.1 \mathrm{ml}$ on plating medium listeria agar (Difco) for L. monocytogenes, brilliant green novobiocin agar (Difco) for S. Typhimurium and mannitol salt agar (Difco) for $S$. aureus. The plates were incubated at $37^{\circ} \mathrm{C}$ overnight before colonies were counted, calculated and expressed as $\log _{10} \mathrm{cfu} \mathrm{g}^{-1}$ skin.

Plating from non- inoculated wings to determine shelf life was done on nutrient agar (Difco) at $20^{\circ} \mathrm{C}$ after $0,1,3$ and 5 days of storage at $4^{\circ} \mathrm{C}$. The nutrient agar plates were incubated for $72 \mathrm{~h}$.

For $\mathrm{pH}$ determination, $5 \mathrm{~g}$ of skin wings were placed in a blender with $15 \mathrm{ml}$ of sterile distilled deionized water and blended for $2 \mathrm{~min}$ in a blender. The $\mathrm{pH}$ was measured using $\mathrm{pH}$ meter.

Statistical method

Statistical tests were performed on obtained data using SPSS 11 (2002) computer program. All results with $\mathrm{P}<0.05$ were considered statistically significant. 


\section{RESULTS AND DISCUSSION}

Bacterial contamination of poultry during commercial processing is undesirable, though unavoidable. Not only does contamination of poultry by pathogenic microorganisms pose a health hazard to human, but, spoilage of poultry meat is one of the major causes of economic loss to both consumer as well as producer.

In this study, the decontamination of inoculated chicken wings with three common pathogenic bacteria gave significantly different results (Table 1). Populations of L. monocytogenes, S. Typhimurium and $S$. aureus recovered from chicken wings immediately after inoculation were 7.6, 6.7 and $6.4 \log _{10}$ cfu g $\mathrm{g}^{-1} \mathrm{skin}$, respectively. Table 1 shows the microbial counts on $0,1,3$ and 5 days of $L$. monocytogenes, $S$. Typhimurium and $S$. aureus recovered from inoculated chicken wings which were treated in tap water, TSP, lactic acid and acetic acid prior to refrigerated storage at $4^{\circ} \mathrm{C}$. All the decontamination treatments reduced inoculated bacterial pathogens.

Both $12 \%$ TSP and $1 \%$ lactic acid were very effective in inactivating $L$. monocytogenes since significant reductions in the bacterial populations were observed on day $0,1,3$ and 5 day of refrigeration storage when compared to tap water dipping. As can be seen from Table 1, L. monocytogenes reduction in treated samples with $8,10,12 \%$ TSP and $1 \%$ lactic acid were $5.7 \pm 0.36,5.9 \pm 0.13,4.91 \pm$ 0.02 and $4.4 \pm 0.19$ respectively, after 5 days of refrigerated storage at $4{ }^{\circ} \mathrm{C}$.

When comparing the present results with those of other authors $(\mathrm{Mu}$ et al., 1997) they did not find any significant reduction in L. monocytogenes population either in artificially contaminated fresh headed shrimp or rainbow trout fillets which had been dipped in 10 and $20 \%$ TSP solution for $10 \mathrm{~min}$. This could be explained by Capita et al. (2002) who suggested that decontamination depends on the difference in treatment time, TSP concentration and that the type of tissue studied must be taken into account. Hwang and Beuchat (1995) dipped fragments of chicken skin artificially contaminated with L. monocytogenes in $1 \%$ TSP solutions for $30 \mathrm{~min}$. and found reductions of $1.3 \log _{10}$ cycles after treatment.

Concerning the decontamination effect of lactic acid, the results of this study agree with the study of Greer and Dilts (1995), who reported that L. monocytogenes and other psychrotrophic meat pathogens were more sensitive to organic acid than mesophilic pathogens.

From Table 1, it is clear that the antimicrobial effects of $8,10 \& 12 \%$ TSP and $1 \%$ lactic acid against $S$. Typhimurium $3.81 \pm 0.08,3.69 \pm 0.075,3.26 \pm 0.36$ and $2.28 \pm 0.11 \log _{10} \mathrm{cfu} \mathrm{g}^{-1}$ skin are more effective than their effect against $S$. aureus 4.1 $\pm 0.15,3.79 \pm 0.07,3.30 \pm 0.08$ and $3.14 \pm 0.20 \log _{10} \mathrm{cfu} \mathrm{g}^{-1}$ skin, respectively, after 5 days of storage. These results agree with the study of Hwang and Beuchat (1995) 
who suggested that $1 \%$ TSP, $1 \%$ lactic acid and $0.05 \% \mathrm{NaOH}$ were all effective in reducing the number of viable Salmonella spp. cells on chicken skin. Also, Surve et al. (1991) suggested that the antibacterial effects of lactic acid and acid mixtures (acetic acid and propionic acid) against Gram negative organisms are generally more extensive than their effects against Gram positive organisms.

The concentration of the TSP solution was a significant factor in reducing bacterial population (Table 1). This result agrees with Capita et al. (2002) who suggested that the concentration of TSP solution was a significant factor in reducing the populations of L. monocytogenes. On the contrary, Dickson et al. (1994), found no significant differences in bacterial reductions when different TSP concentrations were used. However, differences were observed when other tissue types were investigated with reduction on adipose greater than those on lean tissue.

From Table 1, it is clear that all pathogens were inactivated faster in $1 \%$ lactic acid than in $2 \%$ acetic acid at the same pH $(1.8-2)$. Populations of $L$. monocytogenes, S. Typhimurium and $S$. aureus recovered from acetic acid treated chicken wings were $5.91 \pm 0.08,3.56 \pm 0.27$ and $3.83 \pm 0.19 \log _{10} \mathrm{cfu} \mathrm{g}^{-1} \mathrm{skin}$, respectively, after 5 days of refrigerated storage. This result suggested that there are other important factors in addition to $\mathrm{pH}$ which influence the antimicrobial effect of lactic acid and acetic acid. In this concern, Samelis et al. (2001) suggested that the lower effectiveness of acetic acid might be due to potentially faster dissipated rate of acetic acid during storage. Sinhamahapatra et al. (2004) explained the mode of action of lactic acid which in dissociated form passes across the cell membrane, dissociates within the cell, acidifies cell interiors and causes retardation of microbial growth.

In this study, it was noticed that the benefit of using either TSP, lactic or acetic acid as decontaminant was apparent after several days of storage, as L. monocytogenes is a psychrotrophic microorganism. Populations in control samples increased from the first day of refrigerated storage approximately $6.95 \pm 0.09 \log _{10}$ cfu $\mathrm{g}^{-1}$ skin and counts on day 3 and 5 were significantly higher $(8.3 \pm 0.06$ and 8.33 $\pm 0.06)$ than counts on day 0 and $1(7.20 \pm 0.16$ and $6.95 \pm 0.09)$, respectively. Populations in treated samples with 8, 10,12\% TSP, $1 \%$ lactic acid and $2 \%$ acetic acid were $5.92 \pm 0.1,5.81 \pm 0.07,5.4 \pm 0.41,4.95 \pm 0.08$ and $5.78 \pm 0.13 \log _{10}$ cfu $\mathrm{g}^{-1}$ skin after 3 days of storage. Similar results were obtained by Colin and Salvat (1996) who suggested an increase in TSP efficiency after several days of refrigerated storage. Also, Capita et al. (2002) indicated that the antimicrobial effect of TSP on L. monocytogenes population was maintained throughout the refrigerated storage, thereby, impede their multiplication on the poultry products.

On the other hand, S. Typhimurium and S. aureus counts on TSP, lactic acid and acetic acid treatment did not significantly change over the storage period (Table 
1), possibly as a result of the inhibitory effect of the residue of decontamination on the chicken wings skin, and they are not psychrotrophic microorganisms.

The results of skin pH on $0,1,3$ and 5 days of bacterial inoculated chicken wings were observed in Table 2. It is clear that dipping of chicken wings in TSP solution resulted relatively in high surface $\mathrm{pH}$ value between $8.3 \pm 0.15$ and $9.07 \pm$ 0.04 initially to the range between $8.12 \pm 0.07$ and $8.15 \pm 0.04$ within 3 days of storage at $4^{\circ} \mathrm{C}$ compared to surface $\mathrm{pH}$ value of samples dipped in tap water (6.64 \pm 0.11) (Table 2). This result could be explained by Mu et al. (1997) who suggested that the natural buffering capacity of food systems, as well as acid production due to microbial growth probably both contributed to the drop of $\mathrm{pH}$ value. The concentration of TSP did not significantly affect the pH of chicken skin on day 1,3 and 5 of storage (Table 2).

On the other hand, the $\mathrm{pH}$ values of the chicken wings remained constant until day 3 in the $1 \%$ lactic and $2 \%$ acetic acid dipped samples $6.58 \pm 0.07$ and 6.45 \pm 0.11 , respectively, and increased slightly between 3 and 5 days of refrigerated storage (Table 2). This pH maintenance was explained by Gibson (1988) who suggested that meat and meat products have a marked buffering capacity which can limit changes in $\mathrm{pH}$ induced by microbial metabolites. Also, Sinhamahapatra et al. (2004) explained that lactic acid penetrates the muscle during treatment, that is why the $\mathrm{pH}$ at $\mathrm{O}$ hours of the lactic acid treated carcass was lower than the untreated control one. The strength of the lactic acid solution was not so high that it prevents the raise of $\mathrm{pH}$ following storage, but, due to its better penetrating capacity, it was able to control the rise in $\mathrm{pH}$ at 24 and $48 \mathrm{~h}$.

Generally speaking, the mechanism by which TSP, lactic acid and acetic acid kill surface bacteria on poultry meat may be a result of combination of $\mathrm{pH}$ factor and a specific antimicrobial effect, however, it appears that L. monocytogenes is more resistant to alkaline $\mathrm{pH}$ than to acidic $\mathrm{pH}$.

To evaluate the effect of decontamination treatment on the natural spoilage micro flora, and thus, on the shelf-life of the product is shown in Table 3. On day 1, there was a higher number of spoilage organism on the surface of chicken wings in the untreated group $5.41 \pm 0.07$ compared to the $8,10 \& 12 \%$ TSP, $1 \%$ lactic and $2 \%$ acetic acid treated groups which were $2.74 \pm 0.1,2.42 \pm 0.07,1.01 \pm 0.09,1.21$ \pm 0.36 and $1.95 \pm 0.29 \log _{10}$ cfu g $g^{-1}$ skin, respectively. The apparent slower growth of bacteria on the control during storage may be due to the high initial numbers of organisms. However, on 5 days of storage, the numbers on the controls were $7.65 \pm$ $0.11 \log _{10}$ cfu g ${ }^{-1}$ skin compared to $8,10 \& 12 \%$ TSP, $1 \%$ lactic and $2 \%$ acetic acid treated groups which were $2.2 \pm 0.15,2.03 \pm 0.04,0.93 \pm 0.06,0.92 \pm 0.06$ and $1.69 \pm 0.55 \log _{10}$ cfu g $^{-1}$ skin, respectively. 
It appears that, $12 \%$ TSP and $1 \%$ lactic acid solutions were most effective, and significantly reduced population of spoilage bacteria on chicken wings when compared to $8,10 \%$ TSP and $2 \%$ acetic acid (Table 3 ).

From this result, it is concluded that decontamination treatment specially 12 $\%$ TSP and $1 \%$ lactic acid retarded the growth of spoilage bacteria on chicken wings, thus, potentially may extend the shelf-life.

The interaction between decontamination treatment and hot water $70^{\circ} \mathrm{C}$ had an additive effect on inoculated bacterial pathogens (Table 4). Comparing the result obtained in Table 1 with the result in Table 4, it was concluded that, none of the individual treatments achieved a high degree of pathogen reduction, but, when the treatment was combined, the effect was more notable. The reductions were $3.88 \pm$ $0.40,3.32 \pm 0.31$ and $4.7 \pm 0.15$ for L. monocytogenes, $2.34 \pm 0.30,1.84 \pm 0.15$ and $2.34 \pm 0.27$ for $S$. Typhimurium and $3.14 \pm 0.28,3.0 \pm 0.35$ and $3.62 \pm 0.19$ for S. aureus after combined treatment $12 \%$ TSP or $1 \%$ lactic or $2 \%$ acetic acid with hot water, respectively, after 5 days of storage. This effect is reasonable since the two treatments have different mechanisms of action. In this aspect, Rodriguez de Ledesma et al. (1996) suggested that TSP probably has a detergent effect making clumps of the cells split and loose from the skin while, hot water results in direct heat kill of bacteria.

It was noticed that the effect of combined treatment on spoilage bacteria was higher than the effect on inoculated pathogenic bacteria (Table 4). The reduction was $2.20 \pm 0.15,1.80 \pm 0.15,0.62 \pm 0.11,0.61 \pm 0.09$ and $0.97 \pm 0.13$ after combined treatment $8,10,12 \%$ TSP, $1 \%$ lactic acid and $2 \%$ acetic acid with hot water, respectively, after 5 days of storage.

TSP, lactic acid and acetic acid are more effective than hot water against $S$. Typhimurium, $S$. aureus and spoilage micro flora, while, there is no clear difference for L. monocytogenes except after 3 days of storage at $4^{\circ} \mathrm{C}$ (Table 4 ).

The antimicrobial effect of decontamination treatment followed by dipping in hot water $70^{\circ} \mathrm{C}$ could maintain throughout the refrigerated storage for inoculated bacteria and spoilage micro flora (Table 4).

It is concluded that all the decontaminants were effective in reducing inoculated bacterial pathogens and spoilage micro flora, but, $12 \%$ TSP and $1 \%$ lactic acid were more effective. We advice to extend the use of combined decontamination treatment and hot water at $70^{\circ} \mathrm{C}$ to poultry industry as an effective means to reduce bacterial population and extension of shelf-life of chilled poultry. 


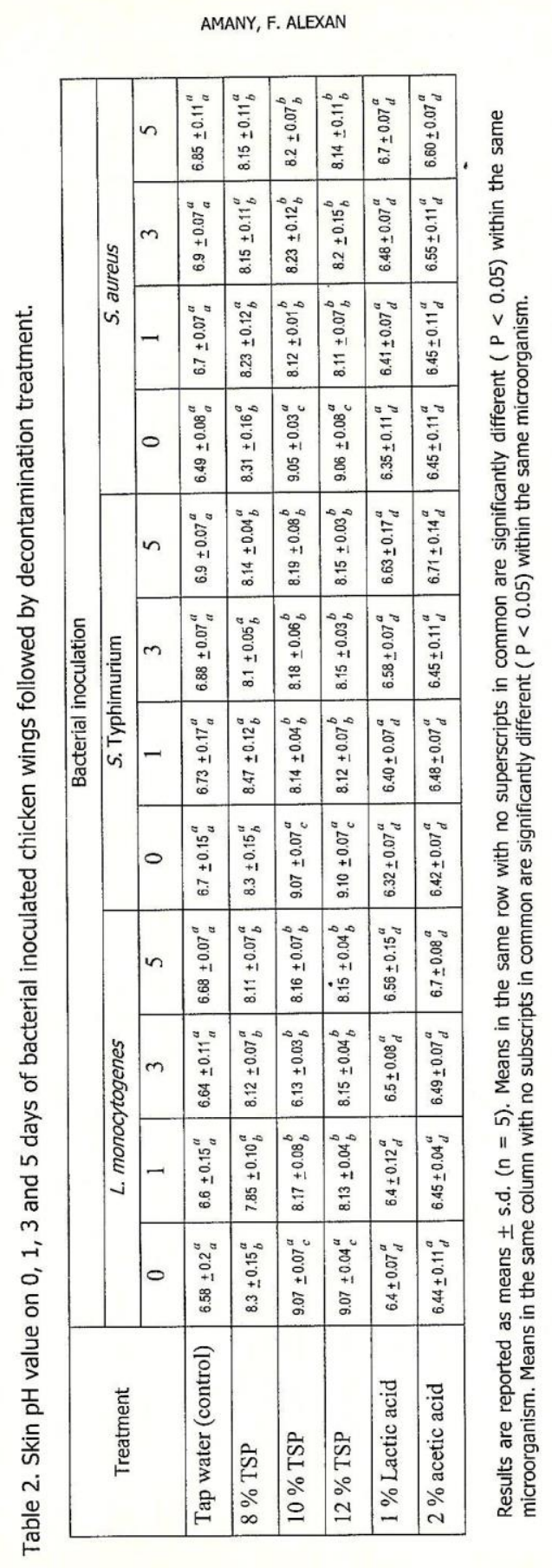

301 


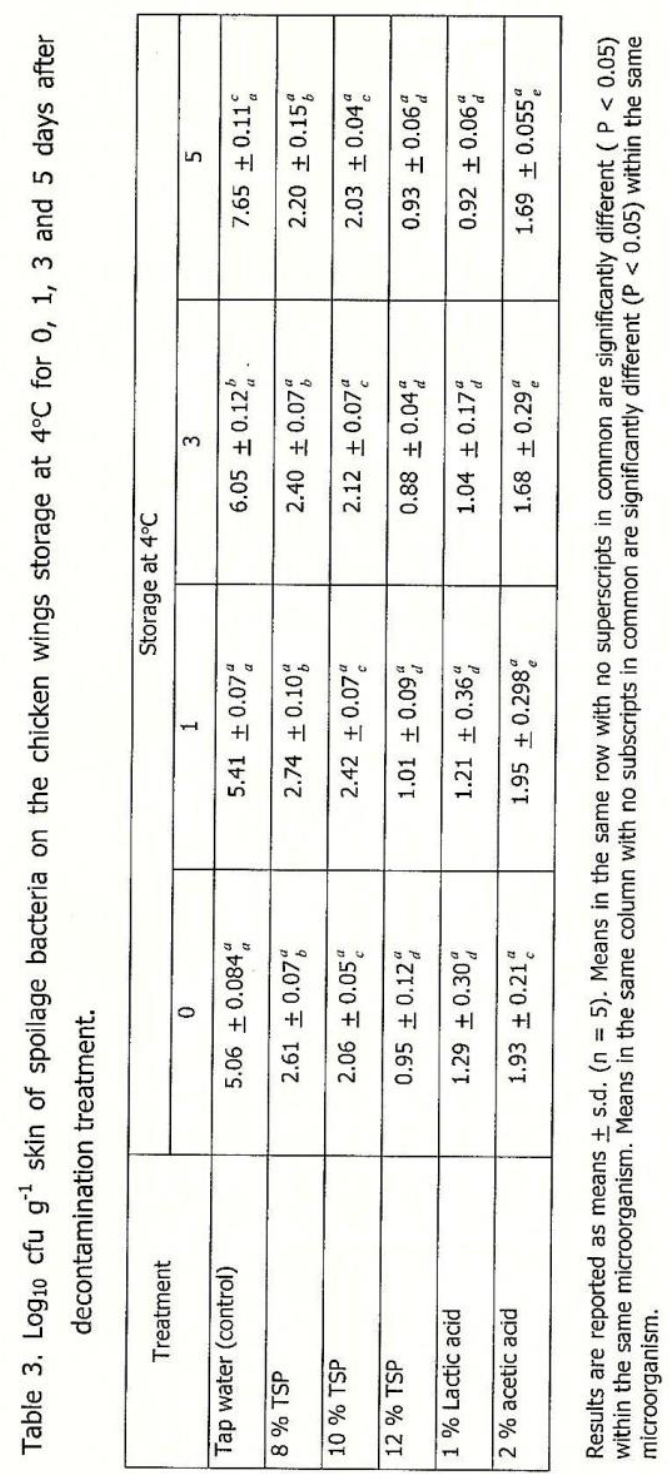




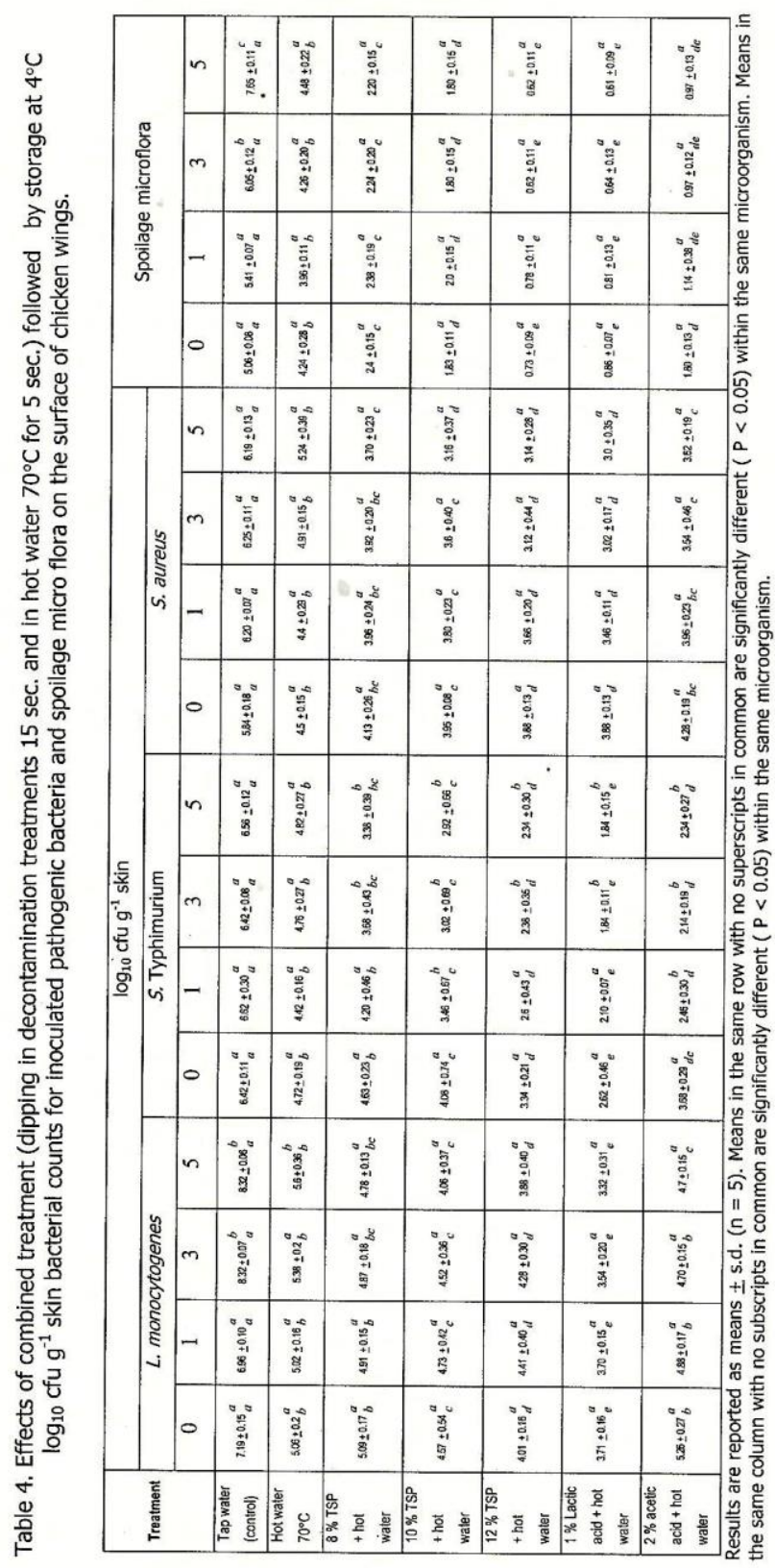




\section{REFERENCES}

1. Capita, R., M. Alonso-Calleja, M. del Camino Garcia Fernandez, and B. Moreno. 2002. Activity of trisodium phosphate compared with sodium hydroxide wash solutions against Listeria monocytogenes attached to chicken skin during refrigerated storage. Food Microbiol, 19: 57 - 63 .

2. Colin, P. and G. Salvat. 1996. Decontamination of poultry carcasses using trisodium phosphate treatment. Microbiol Methods for the meat industry concerted Action, CT94 - 1456 pp. 227 - 237.

3. Dickson, J. S., C. G. N. Cutter and G. R. Siragusa. 1994. Antimicrobial effects of trisodium phosphate against bacteria attached to beef tissue. J. Food Prot., 57: $952-955$.

4. Del Rio, E., R. Capita, M. Prieto and C. Alonso-Calleja. 2006. Comparison of pathogenic and spoilage bacterial levels on refrigerated poultry parts following treatment with trisodium phosphate. Food Microbiol, 23 (2): 195 - 198.

5. Gibson, D. M. 1988. Microbial spoilage of foods. In Microorganisms in action, concepts and applications in microbial ecology (Eds. J. E. Hobbie and J. M. Lynch) pp. $288-321$.

6. Greer, G. G. and B. D. Dilts. 1995. Lactic acid inhibition of the growth of spoilage bacteria and cold tolerant pathogens on pork. Int. J. Food Microbiol, 25: 141 - 151.

7. Hwang, C. A. and L. R. Beuchat. 1995. Efficacy of selected chemicals for killing pathogenic and spoilage microorganisms on chicken skin. J. Food Prot., 58: $19-$ 23.

8. Lillard, H. S. 1985. Bacterial cell characteristics and conditions influencing their adhesion to poultry skin. J. Food Prot., 48: 803 - 807 .

9. Mu, D, Y. W. Huang, K. W Gates, and W. H. Wu.1997. Effects of trisodium phosphate on Listeria monocytogenes attached to rainbow trout and shrimp during refrigerated storage. J. Food Safety, 17: 37 - 46.

10. Rodriguez de Ledesma, A. M., M. R. Riemann and T. V. Farven. 1996. Short-time treatment with alkali and/or hot water to remove common pathogenic and spoilage bacteria from chicken wing skin. J. Food Prot., 59 (7): 746 - 750.

11. Ryser, E. T. 1999. Food borne listeriosis. In Listeria, listeriosis and food safety (Eds. Ryser E. T. And Marth E. M.) pp. $299-358$. 
12. Samelis, J., N. John, Sofos, A. Patricia Kendall and C. Gray Smith. 2001. Fate of Escherichia coli 0157:H7, Salmonella Typhimurium DT104 and Listeria monocytogenes in fresh meat decontamination fluids at 4 and $10^{\circ} \mathrm{C}$. J. Food Prot., 64 (7): $950-957$.

13. Sinhamahapatra, M., S. Biswos, A. K. Das and D. Bhattacharyya. 2004.Comparative study of different surface decontaminants on chicken quality. $\mathrm{Br}$. Poult. Sci., 45 (5): $624-630$.

14. SPSS, 11. 2002. Statistical Package for Social Science, SPSS for windows Release 11.0.0, and 12 June, 2002. Standard Version, Copyright SPSS Inc., 1989-2002, All Rights Reserved, Copyright @ SPSS Inc.

15. Surve, A. N., A. T. Sherikar, K. N. Bhilegaonkar and U. D. Karkare. 1991. Preservative effect of combination of acetic acid with lactic acid or prop ionic acid on buffalo meat stored at refrigeration temperature. Meat Sci., 29: $309-322$. 
إستخدام مضادات التلوث فى السيطرة علي البكتريا الموجودة في جلا الدواجن

$$
\text { أماني فتحي ألكسان }
$$

معهز بحوث صحة الحيوان- مركز البحوث الزراعية- وزارة الزراعة- الدقي- جيزة

هذه دراسة مقارنة عن تأثير إبتذام مضادات التلوث المختلفة لتقليل التو اجد البكتيري الناتج من ميكروفلوراطبيعية أو بعض ميكروبات التسم الغذائي المحقونة في أجنحة الدواجن.

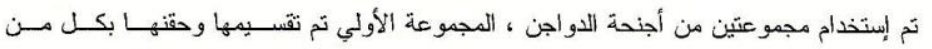

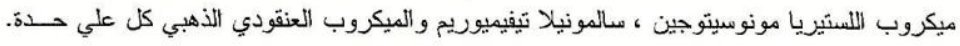

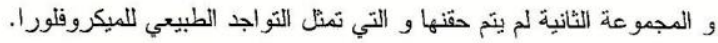

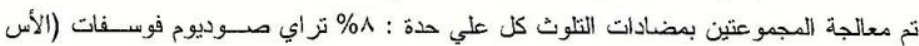

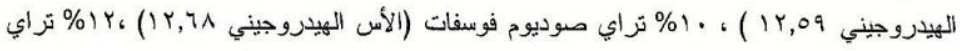

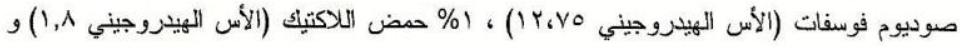

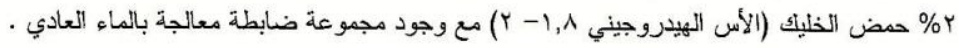
وتم دراسة المعالجة المزدوجة وذلك باستخدام مضادات التلوث السابقة كل علي حدة يليها إستخدام

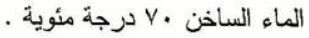

وتم الثقييم بعمل العد البكتيري وقياس الأس الهيليروجيني بعد المعالجة مباشرة وبعد ا،با،ه أيام .

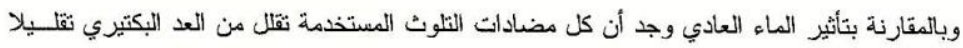

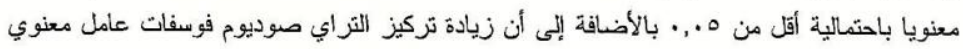

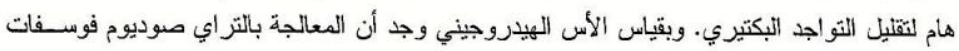

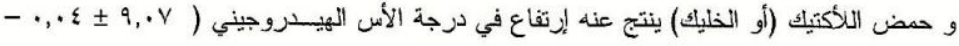
r,

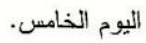
إن مضادات التلوث المختلفة تقلل من نمو الميكروفلورا الطبيعية وذلك قد يزيد من مدي صلاحية المبادية

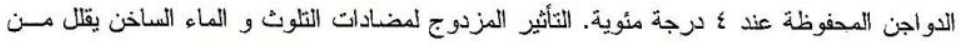

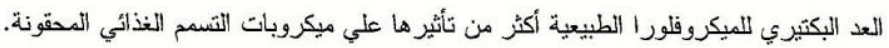

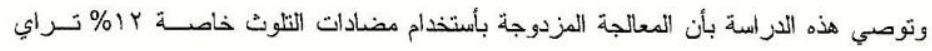

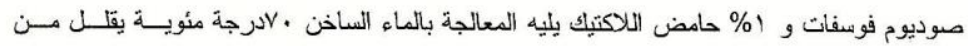

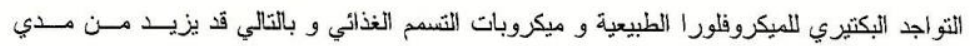
صلاحية الدواجن ويقلل من حدوث حالات التسمم الغذائي. 